\title{
The utility of inflammatory markers to predict readmissions and mortality in COPD cases with or without eosinophilia [Corrigendum]
}

\author{
Duman D, Aksoy E, Agca MC, et al. International Journal \\ of COPD. 2015;10(1):2469-2478.
}

Page 2475, Table 4, the second column heading "Odds ratio" is incorrect. The correct column heading is "Hazard ratio".

The International Journal of COPD is an international, peer-reviewed journal of therapeutics and pharmacology focusing on concise rapid reporting of clinical studies and reviews in COPD. Special focus is given to the pathophysiological processes underlying the disease, intervention programs, patient focused education, and self management protocols.
This journal is indexed on PubMed Central, MedLine and CAS. The manuscript management system is completely online and includes a very quick and fair peer-review system, which is all easy to use. Visit http://www.dovepress.com/testimonials.php to read real quotes from published authors.

Submit your manuscript here: http://www.dovepress.com/international-journal-of-chronic-obstructive-pulmonary-disease-journal

submit your manuscript | www.dovepress.com Dovepress

http://dx.doi.org/10.2147/COPD.S103721 